\title{
A Study of Storage Related Changes and Effect of Refrigeration on Hematological Parameters and Blood Cell Morphology in EDTA An-ticoagulated Blood
}

\author{
Debdatta Basu ${ }^{1 *}$ and Harsha Veluru ${ }^{2}$ \\ ${ }^{1}$ Department of Pathology, JIPMER, Puducherry - 605006, India \\ ${ }^{2}$ Under-graduate, JIPMER, Puducherry . India
}

\begin{abstract}
Introduction: Delayed sample analysis result in changes in measured parameters and mor-phology of cells, leading to erroneous reports of complete blood counts and peripheral smear reporting. The present study was aimed at evaluating the changes in blood cell counts and morphology on storage, particularly in the local setting and temperature of a tropical country.

Materials \& Methods: 190 patients referred to the laboratory for complete blood counts and peripheral smear exam-inations were included in the study. Blood counts and peripheral smear examination was done at $0,2,6$, and 24 hours.

The 6 and 24 hour samples were further studied under three different temperatures, refrigerated, ambient room temperature and at $37^{\circ} \mathrm{C}$.

Statistical difference between values of studied parameter at different time interval was tested using paired t-test. $\mathrm{P}<0.05$ was considered for statistical significance.

Results: There was no significant difference between 0 hour\& 2 hour samples in any of the parameters. However a significant change was noted in the platelet count between 6 hour re-frigerated and 6 hour un-refrigerated. All the red cell parameters and platelet counts and cell morphology were significantly altered at 24 hours in refrigerated and unrefrigerated samples.

Conclusions: Storage of EDTA blood causes changes in the counts and morphology of the cells. Within 2 hours no changes are expected, however if there is an anticipated delay beyond 2 hours, it is worthwhile to refrigerate the samples up to 6 hours, especially when platelet counts are desired.
\end{abstract}

Keywords: Storage Artifacts, Blood Cell Count, EDTA, Blood Cell Morphology.

\section{Introduction}

Accurate hematological reporting is vital for proper management of patients and comprises of complete blood counts $(\mathrm{CBC})$ derived from the automated cell counter as well as the morphological assessment of a peripheral blood smear. Reliable specimen collection and transfer to the laboratory are fundamental to obtain high-quality test results in the hematology laboratory. ${ }^{[1]}$ Dipotassium EDTA dihydrate $\left(\mathrm{K}_{2}\right.$ EDTA. $\left.2 \mathrm{H}_{2} \mathrm{O}\right)$ is the anticoagulant of choice for modern automated $\mathrm{CBC}$ analyzers. ${ }^{[2]}$ Hematological results are often influenced by a number of pre-analytical variables, the time lapse between when the sample was taken and when they were analyzed, that is storage time in EDTA, being one of the significant ones. ${ }^{[1]}$ Delayed sample analysis results in changes in the measured parameter and morphology of cells, leading to erroneous reports which could complicate the interpretation of the resulting data. ${ }^{[2]}$ In our institute, the main hematology laboratory receives samples from various wards and casualty. These wards are at diverse locations spread over 198 acres of the campus.
Due to a diverse source of the samples and specific lab timings, there are high chances for a delay between sample collection and processing.

According to studies by Turhan et al and Gulati et al, parameters like RBC, WBC, Hemoglobin and platelets remain stable at room temperature even after 48 hours. ${ }^{[3,4]}$ These studies were however done in countries with moderate climate. Another study from Pondicherry, located in the southern part of India, contrastingly states that statistically significant increased WBC and decreased RBC values were noticed at $27^{\circ} \mathrm{C}$ within 24 hours however there was no significant difference in hemoglobin concentration at $4^{\circ} \mathrm{C}$ and $27^{\circ} \mathrm{C}$ even up to 72 hours storage.$^{[5]}$ Among blood cell parameters tested, the white cell count, red cell count and hemoglobin levels were found to be stable for up to 72 hours. ${ }^{[6]}$ In a study on normal healthy blood donors it was found that blood stored at $4^{\circ} \mathrm{C}$ did not show any change in parameters for three days whereas changes were observed when kept at room temperature in 24 hours. ${ }^{[7]}$ Films made from blood stored not more than one hour do not show 
any morphological changes while by $12-18$ hours, striking morphological changes, especially in WBC, are noted at room temperature. ${ }^{[8]}$ This necessitates refrigeration at $4^{0} \mathrm{C}$ whenever samples have to be stored above 8 hours especially for the morphological interpretation of the smear. ${ }^{[8,9]}$ According to guidelines of International Society for Laboratory Hematology morphological changes in blood cells begin within 30 minutes of the collection of a sample. ${ }^{[10]}$ The guidelines further state that if EDTA-anticoagulated whole blood has to be used for performing blood smears, the quality of the smears cannot be guaranteed after 6 hours of blood drawing even if specimens are kept at $4^{\circ} \mathrm{C} . .^{[10]}$

To the best of our knowledge, none of the studies has included the effect of time and temperature, especially in a place with a hot climate (ranges from $24-40^{\circ} \mathrm{C}$ ), on the stability of both counts as well as the morphology of the blood cells. Hence it is imperative to evaluate the storage conditions and sensitize clinicians and laboratory personnel about these changes, particularly in our setting in order to ensure the quality of our reports.

\section{Materials \& Methods}

The study was conducted after obtaining clearance from the Undergraduate Research Monitoring Committee and Institute Ethics Committee. 190 patients referred to the main hematology laboratory for complete blood counts and peripheral smear examinations were included in the study. $2 \mathrm{ml}$ EDTA anticoagulated blood samples were collected. At 0 hours, following parameters derived from automated counters, SYSMEX K 2000i were studied - Hemoglobin, RBC count, MCV, MCH, MCHC, WBC count and Platelet count. The peripheral smear was stained by Leishman stain studied for morphology of RBC, WBC and Platelets. The sample was then stored for 2, 6 and 24 hours at ambient laboratory temperature. The 6 and 24 hour samples were further studied under three temperatures of refrigerated (4 to $8^{\circ} \mathrm{C}$ ), in ambient lab temperature of $22-23^{\circ} \mathrm{C}$ and at $37^{\circ} \mathrm{C}$ conditions. All the above-mentioned parameters were studied in each of the storage conditions the peripheral smears were studied at $0,2,6$ and 24 hours and at the various temperatures for morphological changes in RBC, WBC and Platelets. ${ }^{[9]}$

Following morphological parameters were studied -

RBC:-

a) Crenation artefact with loss of central pallor

b) Spherocytic forms

WBC:-

a) Abnormal chromatin clumping

b) Cytoplasmic fragmentation/vacuolization c) Degranulation or Pelguer-Huet forms

d) Abnormal nuclear lobulation

Platelets:-

a) Presence or absence of clumping

b) Degranulation

c) Large platelets

For RBC related morphological changes, each of the parameters was scored using criteria similar to that used by Cora et al. ${ }^{[1]}$ It included-

Occasional- Present only in a random field

1+: 1-5 altered RBCs present in each field

2+: 6-15 altered RBCs present in each field

3+: 16-25 altered RBCs present in each field

4+: More than 25 altered RBCs in each field. For statistical purpose Occasional and 1+ were grouped together as not significant.

For WBC related parameters, the proportion of WBCs showing the morphological changes (expressed as the percentage of total WBCs) was noted.

For platelet related parameters, only the presence or absence of the finding was noted.

Statistical difference between values of the studied parameter at different time interval was tested using paired t-test. $\mathrm{P}<0.05$ was considered for statistical significance.

\section{Results}

Changes in Morphology of RBC: Changes in red cell morphology were observed from the $6^{\text {th }}$ hour in a refrigerated condition. The major change observed was cell shrinkage with crenations (Figure-1;). The changes were significantly more in the un-refrigerated samples in both at both 6 hours and 24 hour samples. The samples incubated at $37^{\circ} \mathrm{C}$ at 6 hours and 24 hours had more degree of crenation as compared to their respective samples in both refrigerated and un-refrigerated condition. Figure-2).

Wbc Degeneration: The WBCs showed cytoplasmic vacuolations and cytoplasmic fragmentation. WBC degeneration started at $6^{\text {th }}$ hour in the refrigerated samples, there was a significant increase in the degeneration in the un-refrigerated samples. There is a decrease in the amount of degeneration in the 24 hour refrigerated samples (Figure-1, 3; ) as compared to the 6 hours both refrigerated and un-refrigerated samples, 24 hours $\left(37^{\circ} \mathrm{C}\right)$ samples show the maximum amount of degeneration. (Figure-4),

Changes In Platelet Morphology: The degenerative morphological changes in the platelets especially scattering 
(Figure 1) anddegranulation were observed from 2-hour samples (Table:1). Giant platelets were observed from the 6 hour refrigerated sample. In the 6 hour samples, there was a decrease in the scattering and degranulation in the samples incubated at $37^{\circ} \mathrm{C}$. There was a progressive increase in the percentage of giant platelets from $0 \%$ in 2 hour samples to $31.7 \%$ in the 6 hour samples and to $78 \%$ at 24 hour samples.

Changes in CBC: There were no significant changes in the hematological parameters in the 2 hour samples when compared to the results at 0 hours. The change in the hemoglobin in the 6 hours $\left(37^{\circ} \mathrm{C}\right)$ in comparison at 0 hours was significant ( $\mathrm{p}=0.024)$. (Table: 2$)$.

At 6th hour between refrigerated and un-refrigerated samples there were significant changes in $\operatorname{MCV}(\mathrm{p}=0.03)$ and platelet count $(\mathrm{p}=0.000)$.(Table:3) In the 24 hour $\left(37^{\circ} \mathrm{C}\right)$ in comparison to 0 hour along with $\operatorname{MCV}(\mathrm{p}=0.001)$ and platelet counts $(\mathrm{p}=0.001)$ there was also change in $\operatorname{TLC}(\mathrm{p}=0.005)$. In the 24-hour refrigerated and unrefrigerated samples there was change in $\operatorname{MCV}(\mathrm{p}=0.012)$, $\operatorname{MCH}(\mathrm{p}=0.038), \mathrm{MCHC}(\mathrm{p}=0.004)$ and platelet count $(p=0.003)$.

Table 1: Grade of platelet degenerative changes at various storage times and temperature.

\begin{tabular}{|c|c|c|c|}
\hline & Scattering & Degranulation & Giant platelets \\
\hline $2 \mathrm{hr}$ & $47.5 \%$ & $15 \%$ & $0 \%$ \\
\hline $6 \mathrm{hr}$ refrigerated & $90.2 \%$ & $65.9 \%$ & $61 \%$ \\
\hline $6 \mathrm{hr}$ un-refrigerated & $92.7 \%$ & $48.8 \%$ & $31.7 \%$ \\
\hline $6 \mathrm{hr}\left(37^{\circ} \mathrm{C}\right)$ & $80 \%$ & $8 \%$ & $48 \%$ \\
\hline $24 \mathrm{hr}$ refrigerated & $75.6 \%$ & $56.1 \%$ & $51.2 \%$ \\
\hline $24 \mathrm{hr}$ unrefrigerated & $100 \%$ & $78 \%$ & $78 \%$ \\
\hline $24\left(37^{\circ} \mathrm{C}\right)$ & $100 \%$ & $82.9 \%$ & $75.6 \%$ \\
\hline
\end{tabular}

Table 2: Change in the hematological parameters at 6 hours $\left(37^{\circ} \mathrm{C}\right)$ interval in comparisons to 0 hour.

\begin{tabular}{|c|c|c|c|c|}
\hline \multicolumn{5}{|c|}{$0-6\left(37^{\circ} \mathrm{C}\right)$} \\
\hline time and category & Mean & $\mathbf{N}$ & Std. Deviation & $P$ value \\
\hline Ohr hemoglobin & $12.28 \mathrm{~g} \%$ & 25 & 2.14379 & \multirow[t]{2}{*}{0.024} \\
\hline $6 \mathrm{~h}$ hemoglobin $\left(37^{\circ} \mathrm{C}\right)$ & $9.888 \mathrm{~g} \%$ & 25 & 4.673001 & \\
\hline Ohr TLCa & 7.8704 & 25 & 4.942569 & \multirow[t]{2}{*}{0.1} \\
\hline $6 \mathrm{hr}$ TLC & 5.5928 & 25 & 4.076164 & \\
\hline Ohr MCVb & 88.284 & 25 & 18.82015 & \multirow[t]{2}{*}{0.637} \\
\hline $6 \mathrm{hr} \mathrm{MCV}$ & 85.556 & 25 & 23.73635 & \\
\hline $\mathrm{Ohr} \mathrm{MCH}^{\mathrm{c}}$ & 30.372 & 25 & 3.821706 & \multirow[t]{2}{*}{0.504} \\
\hline $6 \mathrm{hr} \mathrm{MCH}$ & 32.884 & 25 & 18.20624 & \\
\hline Ohr MCHCd & 32.016 & 25 & 6.214545 & \multirow[t]{2}{*}{0.41} \\
\hline $6 \mathrm{hr} \mathrm{MCHC}$ & 35.964 & 25 & 22.7991 & \\
\hline $0 \mathrm{hr}$ platelet count & 225.88 & 25 & 121.534 & \multirow[t]{2}{*}{0.458} \\
\hline $6 \mathrm{hr}$ platelet count & 409.136 & 25 & 1224.673 & \\
\hline
\end{tabular}

a-Total Leucocyte count

b-Mean Corpuscular Volume(Femtolitre/cell)

c-Mean Corpuscular Hemoglobin(Picogram/cell)

$d$ - Mean Corpuscular Hemoglobin Concentration $(g / d L)$

e- $* 10^{3} /$ Microlitre 
Table 3: Change in the hematological parameters at 6 hour(refrigerated) interval in comparison to 6 hour(un-refrigerated).

\begin{tabular}{|c|c|c|c|c|c|}
\hline \multicolumn{6}{|c|}{$6 \mathrm{hr}$ refrigerated vs $6 \mathrm{hr}$ unrefrigerated } \\
\hline & time and category & Mean & $\mathbf{N}$ & Std. Deviation & $P$ value \\
\hline \multirow[t]{2}{*}{ Pair 1} & 6hr Hb REFRIGERATED ${ }^{a}$ & 9.946341 & 41 & 3.381575 & \multirow[t]{2}{*}{0.089} \\
\hline & 6hr Hb UNREFRIGERATED & 10.71951 & 41 & 2.833921 & \\
\hline \multirow[t]{2}{*}{ Pair 2} & 6 hr TLC REFRIGERATED ${ }^{\mathbf{b}}$ & 8.81561 & 41 & 6.896628 & \multirow[t]{2}{*}{0.764} \\
\hline & $6 \mathrm{hr}$ TLC UNREFRIGERATED & 8.912439 & 41 & 6.908869 & \\
\hline \multirow[t]{2}{*}{ Pair 3} & 6hr MCV REFRIGERATED ${ }^{c}$ & 88.37073 & 41 & 10.37739 & \multirow[t]{2}{*}{0.03} \\
\hline & $6 \mathrm{hr}$ MCV UNREFRIGERATED & 89.66098 & 41 & 11.34625 & \\
\hline \multirow[t]{2}{*}{ Pair 4} & 6hr MCH REFRIGERATED d & 37.58293 & 41 & 36.47438 & \multirow[t]{2}{*}{0.411} \\
\hline & 6hr MCH UNREFRIGERATED & 33.55122 & 41 & 16.19506 & \\
\hline \multirow[t]{2}{*}{ Pair 5} & 6hr MCHC REFRIGERATEDe & 42.55854 & 41 & 39.66644 & \multirow[t]{2}{*}{0.118} \\
\hline & $\begin{array}{c}\text { 6hr MCHC } \\
\text { UNREFRIGERATED }\end{array}$ & 32.70244 & 41 & 1.448532 & \\
\hline \multirow[t]{3}{*}{ Pair 6} & $6 \mathrm{hr}$ platelet count & 171.32 & 41 & 147.231 & \multirow[t]{3}{*}{0} \\
\hline & REFRIGERATED ${ }^{f}$ & & & & \\
\hline & $\begin{array}{l}6 \mathrm{hr} \text { platelet count } \\
\text { UNREFRIGERATED }\end{array}$ & 215.37 & 41 & 163.026 & \\
\hline
\end{tabular}

a- Hemoglobin (g\%)

$b$ - Total Leucocyte count

c-Mean Corpuscular Volume(Femtolitre/cell)

d-Mean Corpuscular Hemoglobin(Picogram/cell)

e-Mean Corpuscular Hemoglobin Concentration( $g / d L)$

$f$ - $* 10^{3} /$ Microlitre

Table 4: Change in the hematological parameters at 24 hours $\left(37^{\circ} \mathrm{C}\right)$ interval In comparison to 0 hours.

\begin{tabular}{|c|c|c|c|c|c|}
\hline \multicolumn{6}{|c|}{$0 \mathrm{hr}$ vs $24 \mathrm{hr} 37^{\circ} \mathrm{C}$} \\
\hline & time and category & Mean & $\mathbf{N}$ & Std. Deviation & $\mathrm{P}$ value \\
\hline \multirow[t]{2}{*}{ Pair 1} & Ohr Hba & 10.31515 & 33 & 2.499765 & \multirow[t]{2}{*}{0.244} \\
\hline & $24 \mathrm{hr} \mathrm{Hb}$ & 10.34546 & 33 & 2.528351 & \\
\hline \multirow[t]{2}{*}{ Pair 2} & Ohr TLC ${ }^{b}$ & 9.595455 & 33 & 24.20551 & \multirow[t]{2}{*}{0.005} \\
\hline & $24 \mathrm{hr} \operatorname{tlc}\left(37^{\circ} \mathrm{C}\right)$ & 9.287273 & 33 & 23.66817 & \\
\hline \multirow[t]{2}{*}{ Pair 3} & Ohr MCVc & 96.488 & 33 & 9.1416 & \multirow[t]{2}{*}{0.001} \\
\hline & $24 \mathrm{hr} \operatorname{MCV}\left(37^{\circ} \mathrm{C}\right)$ & 115.8152 & 33 & 13.93615 & \\
\hline \multirow[t]{2}{*}{ Pair 4} & $\mathrm{Ohr} \mathrm{MCH}^{\mathrm{d}}$ & 31.62727 & 33 & 3.87123 & \multirow[t]{2}{*}{0.694} \\
\hline & $24 \mathrm{hr} \mathrm{MCH}$ & 31.79091 & 33 & 4.228354 & \\
\hline \multirow[t]{2}{*}{ Pair 5} & Ohr MCHCe & 30.08788 & 33 & 3.198413 & \multirow[t]{2}{*}{0.966} \\
\hline & $24 \mathrm{hr} \mathrm{MCHC}$ & 30.04849 & 33 & 2.485096 & \\
\hline \multirow[t]{2}{*}{ Pair 6} & 0 hr platelet count ${ }^{f}$ & 182.12 & 33 & 122.816 & \multirow[t]{2}{*}{0.001} \\
\hline & $24 \mathrm{hr}$ platelet count $\left(37^{\circ} \mathrm{C}\right)$ & 171.3 & 33 & 112.311 & \\
\hline
\end{tabular}

a- Hemoglobin (g\%)

$b$ - Total Leucocyte count

c-Mean Corpuscular Volume(Femtolitre/cell)

$d$-Mean Corpuscular Hemoglobin(Picogram/cell)

e-Mean Corpuscular Hemoglobin Concentration $(g / d L)$

$f$ - $* 10^{3} /$ Microlitre 
Table 5: Change in the hematological parameters at 24 hours (refrigerated) interval in comparisons to 24 hours (un-refrigerated).

\begin{tabular}{|c|c|c|c|c|}
\hline \multicolumn{5}{|c|}{$24 \mathrm{hr}$ refrigerated vs $24 \mathrm{hr}$ unrefrigerated } \\
\hline time and category & Mean & $\mathbf{N}$ & Std. Deviation & $P$ value \\
\hline 24 hr Hb REFRIGERATEDa & 11.02927 & 41 & 1.723694 & \multirow[t]{2}{*}{0.54} \\
\hline $24 \mathrm{hr} \mathrm{Hb}$ UNREFRIGERATED & 11.15122 & 41 & 1.715827 & \\
\hline 24 hr TLC REFRIGERATED & 5.405854 & 41 & 3.793646 & \multirow[t]{2}{*}{0.15} \\
\hline 24 hr TLC UNREFRIGERATED & 82.67976 & 41 & 342.8415 & \\
\hline 24 hr MCV REFRIGERATED ${ }^{c}$ & 90.62195 & 41 & 8.306429 & \multirow[t]{2}{*}{0.012} \\
\hline 24 hr MCV UNREFRIGERATED & 94.13902 & 41 & 10.14566 & \\
\hline 24 hr MCH REFRIGERATED ${ }^{d}$ & 32.81463 & 41 & 10.02685 & \multirow[t]{2}{*}{0.038} \\
\hline $24 \mathrm{hr} \mathrm{MCH}$ UNREFRIGERATED & 29.3439 & 41 & 4.431989 & \\
\hline 24 hr MCHC REFRIGERATEDe & 33.30488 & 41 & 3.589565 & \multirow[t]{2}{*}{0.004} \\
\hline $24 \mathrm{hr}$ MCHC UNREFRIGERATED & 31.07561 & 41 & 3.576575 & \\
\hline $24 \mathrm{hr}$ platelet count REFRIGERATED ${ }^{f}$ & 144.605 & 41 & 96.7493 & \multirow[t]{2}{*}{0.003} \\
\hline $24 \mathrm{hr}$ platelet count UNREFRIGERATED & 196.44 & 41 & 91.768 & \\
\hline
\end{tabular}

a- Hemoglobin (g\%)

$b$-Total Leucocyte count

c-Mean Corpuscular Volume(Femtolitre/cell)

$d$-Mean Corpuscular Hemoglobin(Picogram/cell)

e- Mean Corpuscular Hemoglobin Concentration $(g / d L)$

$f$ - $* 10^{3} /$ Microlitre

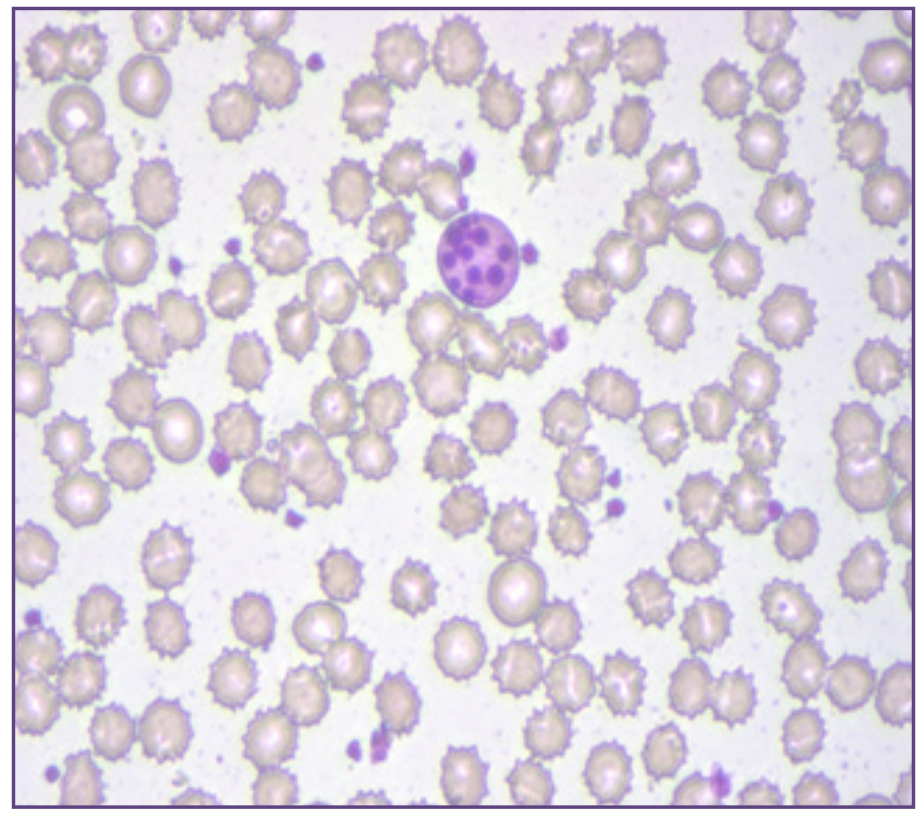

Fig.1: Peripheral smear showing crenated RBCs, apoptotic neutrophils and scattered platelets at 24 hour sample $370 \mathrm{C}$ (Leishman x400). 


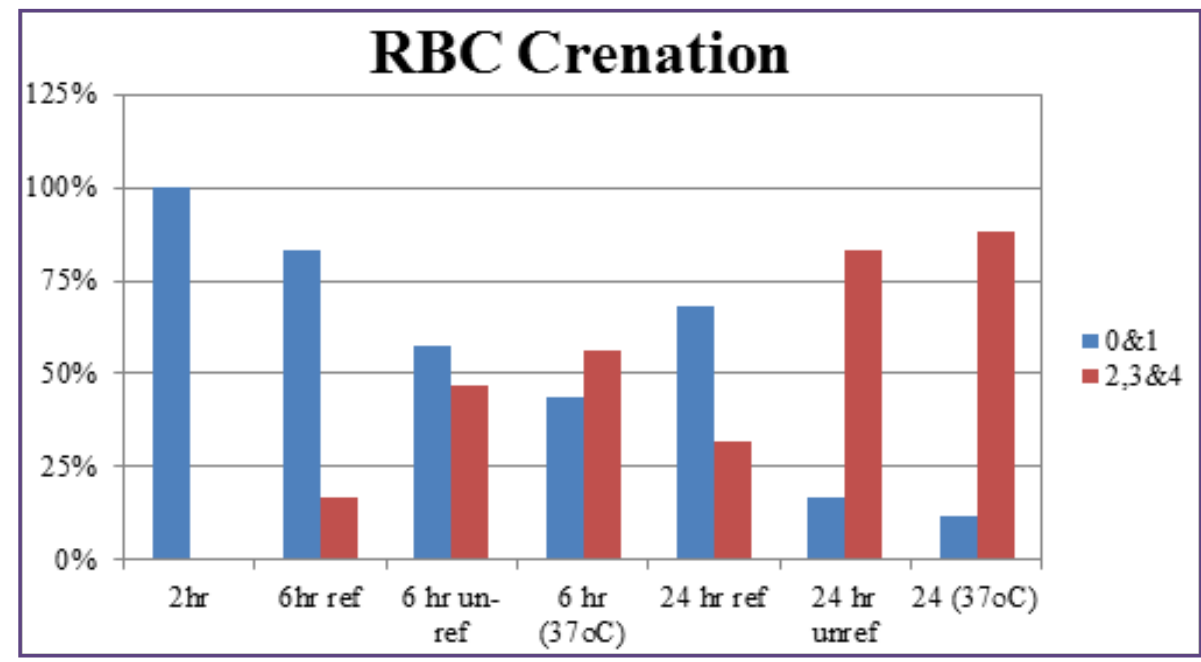

Fig. 2: A graph representing the RBC crenation over the period and at different conditions.

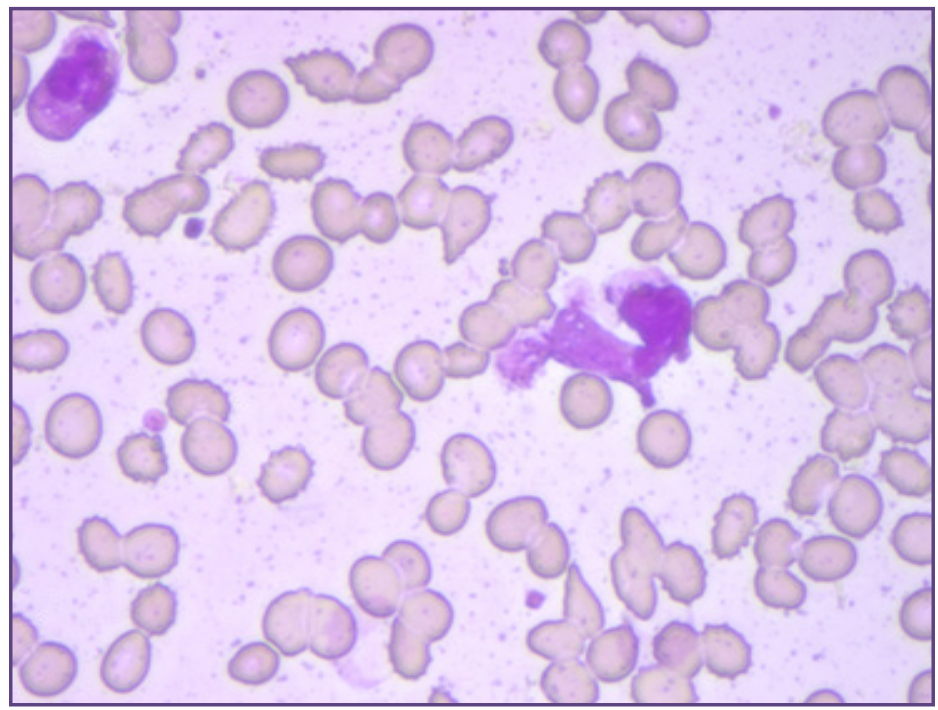

Fig.3: Peripheral blood picture showing degenerated WBCs in a 24 hour refrigerated sample. (Leishmanx400).

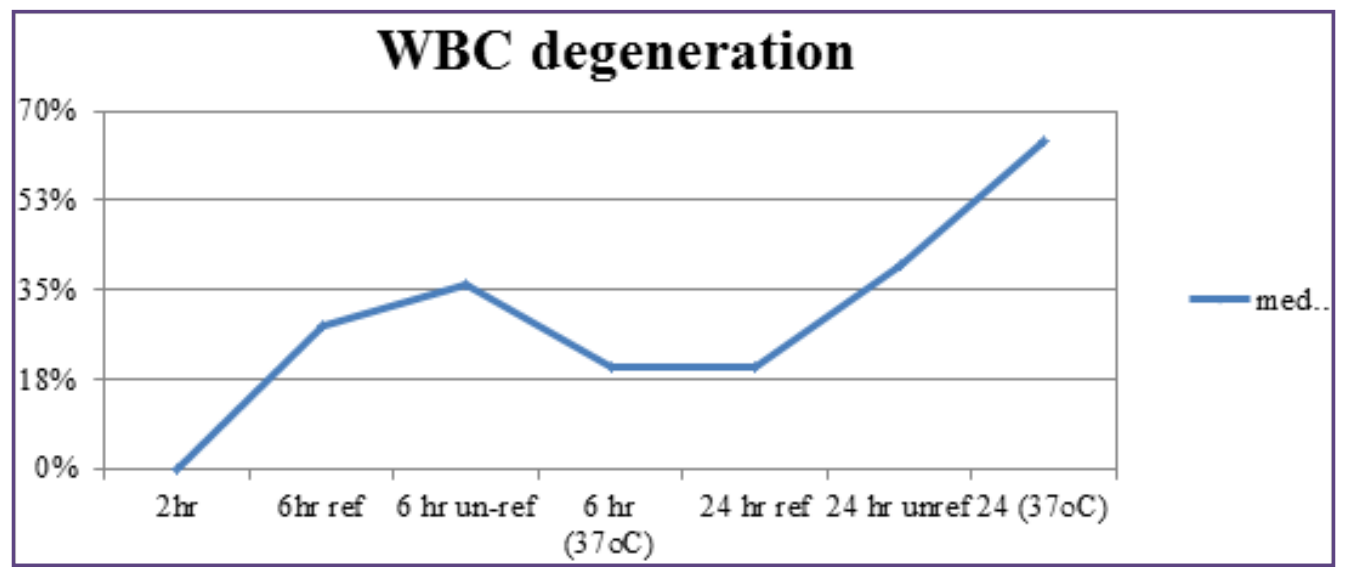

Fig. 4: Plot showing the median percentage of $W B C$ degeneration over the period and at different conditions. 


\section{Discussion}

Knowledge of the effects of temperature on blood sample stability is important in a hematology laboratory. Samples from peripheral collection centres and blood donation camps may have a considerable delay in transport to the central laboratory. In such cases, the samples may be exposed to high temperatures, especially during summer and in tropical conditions. Such exposure of blood samples to high temperatures after collection is especially common in resource-poor areas, but may also happen due to a failure of temperature controlled transport and storage containers. Ideal conditions for storage are relatively uncommon in under-resourced countries, many of which also have a warm to a hot climate for a large portion of the year. A period of storage at high temperature may lead to variation in the different hematology parameters and adversely affect the accuracy of the final report. Therefore, it is important to know which parameters show a clinically significant shift in storage under high temperatures, and which parameters remain relatively stable under the same conditions.

Analytical stability of hematological parameters after varying conditions of sample storage has been researched by many laboratory scientists ${ }^{[12,13,14]}$. However, we still have limited knowledge of analytical stability above $30^{\circ} \mathrm{C}$. Only one study has reported on storage stability above $30^{\circ} \mathrm{C}$, but only for storage up to 24 hours. ${ }^{[12]} \mathrm{A}$ temperature of $37^{\circ} \mathrm{C}$ chosen for this study was close to the average high temperature during summer (April to July) at the place of analysis.

According to Zini, films made from blood stored not more than one hour do not show any morphological changes while by $12-18$ hours, striking morphological changes, especially in WBC, are noted at room temperature.$^{[8]}$ This necessitates refrigeration at $4^{\circ} \mathrm{C}$ whenever samples have to be stored above 8 hours especially for the morphological interpretation of the smear. ${ }^{[8,9]}$ In our study we noticed considerable morphological changes like crenation in the RBCs; degeneration of WBCs in the form of abnormal chromatin clumping, cytoplasmic fragmentation/ vacuolization, degranulation or Pelguer-Huet forms and abnormal nuclear lobulation, and platelet scattering and degranulation. These changes started within 6 hours and progressively increased with time and temperature. The 24 hour sample kept $37^{\circ} \mathrm{C}$ was almost unsuitable for morphological interpretation. According to guidelines of International Society for Laboratory Hematology morphological changes in blood cells begin within 30 minutes of a collection of the sample ${ }^{[10]}$ The guidelines further state that if EDTA-anticoagulated whole blood has to be used for performing blood smears, the quality of the smears cannot be guaranteed after 6 hours of blood drawing even if specimens are kept at $4{ }^{\circ} \mathrm{C} .{ }^{[10]}$

According to studies by Gulati et al and Turhan et al, parameters like RBC, WBC, Hemoglobin and platelets remain stable at room temperature even after 48 hours. ${ }^{[3,4]}$ A study by Mane et al from Pondicherry, contrastingly state that statistically significant increased $\mathrm{WBC}$ and decreased $\mathrm{RBC}$ values were noticed at $27^{\circ} \mathrm{C}$ within 24 hours however there was no significant difference in hemoglobin concentration at $4^{\circ} \mathrm{C}$ and $27^{\circ} \mathrm{C}$ even up to 72 hours storage ${ }^{[5]}$ In another study by Joshi et al, among blood cell parameters tested, the white cell count, red cell count and hemoglobin levels were found to be stable for up to 72 hours however the mean cell volume (MCV) and hematocrit changed significantly following 24-h storage at room temperature. ${ }^{[6]}$

In our study, significant changes in the hemoglobin have been observed from the 6th hour in the refrigerated samples. Platelet counts and MCV were altered significantly in the 6 hour un-refrigerated samples as compared to the refrigerated one. In the 24 hours $\left(37^{\circ} \mathrm{C}\right)$ samples along with MCV and platelet counts, the TLC has also been significantly changed. In the 24 hour un-refrigerated samples all the blood indices are altered along with TLC with respect to the refrigerated one.

A potential limitation is that this study was done under controlled conditions with samples from a varied group of patients. The varying temperature in real life as well as confounding factors arising from an improper draw, mixing, anticoagulation, or individual factors like presence of antibodies and activated complement may conceivably lead to different results. Studies done on patient samples as well as normal samples have shown few differences: ${ }^{[15]}$ the differences are likely to be mild and should not affect the conclusions of the study. The present study has to be interpreted keeping in mind that the analytical stability of a parameter depends on the analyser used.$^{[13]}$ The storage stability of parameters on other analysers using a different technique (e.g. Platelet Counts by the optical method) may vary.

\section{Conclusions}

Storage of EDTA blood causes changes in the counts and morphology of the cells. Within two hours no changes are expected, however, if there is an anticipated delay beyond two hours, it is worthwhile to refrigerate the samples up to six hours, especially when platelet counts are desired. Counts and morphology are unreliable after 24 hours of storage not only at room temperature but also on refrigeration. 


\author{
Abbreviations and Symbols \\ EDTA- Ethylenediaminetetraacetic acid \\ CBC- Complete Blood Count \\ RBC- Red Blood Cells \\ WBC- White Blood Cells \\ MCV- Mean Corpuscular Volume \\ MCH- Mean Corpuscular Hemoglobin \\ MCHC- Mean Corpuscular Hemoglobin
}

\section{Acknowledgements}

I would like to extend my gratitude to senior residents of department of Pathology Dr. Arun Kumar and Dr. Saravana Kumari for their help. I would also like to thank Ms. Saranya (Lab technician) for the technical support. I would like to express my deep appreciation to Dr. Srikanta Kanungo from the Preventive and Social Medicine department for his help in data analysis. I would also like to take this opportunity to thank Yagna Priya Ammakola and Kada Sri Vidhul for their help with the data entry and submission of this project.

\section{References}

1. Narayanan S. The preanalytic phase. An important component of laboratory medicine. Am J Clin Pathol 2000; 113:429-52.

2. Antwi-Baffour S, Quao E, Kyeremeh R, Mahmood SA. Prolong Storage of Blood in EDTA Has an Effect on the Morphology and Osmotic Fragility of Erythrocytes. Int $\mathbf{J}$ Biomed Sci Engg. 2013; 1:20-3.

3. Turhan T, S, Yucel C, Koca Y. Effects of storage conditions on complete blood cell count parameters. Turk J Biochem 2011;36;165-74.

4. Gulati GL. Hyland LJ, Kocher W, Schwarting R. Changes in automated complete blood cell count and differential leukocyte count results induced complete blood cell count and differential leukocyte count results induced by storage of blood at room temperature. Arch Pathol Lab Med 2002;126:336-42

5. Mane M, Kiran CM, Lakshmi TM, Reddy EP. Storage and Stability of Blood Samples - Changes in The Haematological Values. J Pharm Biomed Sci 2014;04:685-7.
6. McVicker W, Segalla R, Favaloro E, Luu V, Vanniasinkam T. Determining the stability of complete blood count parameters in stored blood samples using the SYSMEX XE5000 automated haematology analyser. Int J Lab Hematol. $2015 ; 37: 705-14$

7. Cohle SD, Saleem A, Makkaoui DE. Effects of storage of blood on stability of hematologic parameters. Am J Clin Pathol 1981;76:67-9.

8. Zini, G. International Council for Standardization in haematology (ICSH) (), Stability of complete blood count parameters with storage: toward defined specifications for different diagnostic applications. Int Jnl Lab Hem 2014;36:111-3.

9. Houven B. Blood film preparation and staining procedures. Lab Hematol 2000;6:1-7.

10. Vives-Corrons J-L, Briggs C, Simon-Lopez R, Albarede $\mathrm{S}$, de la Salle B, Flegar-Meatrii Z et al, Effect of EDTA anticoagulated whole blood storage on cell morphology examination. A need for standardization. Int Jnl Lab Hem 2014; 36: 222-6.

11. Cora MC, King D, Betz LJ, Wilson R \& Travlos GS. Artefactual changes in Sprague-dawley rat hematologic parameters after storage of samples C. J Am Assoc Lab Anim Sci 2012; 51: 611-21.

12. Daves M, Zagler EM, Cemin R, Flora F, Joos A, Platzgummer $\mathrm{S}$ et al Blood Sample stability for complete blood cell count using the Sysmex XN haematological analyser. Transfus 2015; 13: 576-82

13. Imeri F, Herklotz R, Risch L, Arbetsleitner C, Zerlauth M, Risch GM, et al. Stability of hematological analytes depends on the hematology analyser used: a stability study with Bayer Advia 120, Beckman Coulter LH 750 and Sysmex XE 2100. Clin Chim Acta 2008; 397:68-71.

14. Buoro S, Mecca T, Seghezzi M, Manenti B, Cerutti L, Dominoni $\mathrm{P}$, et al. Assessment of blood sample stability for complete blood count using the Sysmex XN-9000 and Mindray BC-6800 analyzers. Rev Bras Hematol Hemoter 2016; 38:225-39.

15. Baca ME, Gulati G, Kocher W, Schwarting R. Effects of storage of blood at room temperature on hematologic parameters measured on Sysmex XE-2100. Lab Med2006; $37: 28-36$.

*Corresponding author:

Dr. Debdatta Basu, Professor of Pathology, JIPMER, Puducherry - 605006, India

Phone: +91 9843158620

Email: ddbasu@gmail.com

Financial or other Competing Interests: None. 